Extractiones de Talmud per ordinem sequentialem, edited by Ulisse Cecini and óscar de la Cruz Palma, with assistance from Eulàlia Vernet i Pons and Federico Dal Bo, Corpus Christianorum Continuatio Mediaevalis (CCCM 291), Turnhout, Brepols, 2018, CX+712 pp. ISBN: 9782503582283. Cloth: $€ 420$

Reseñado por IRVEN M. RESNICK

University of Tennessee at Chattanooga, USA Irven-Resnick@utc.edu

Amos Funkenstein once aptly described anti-Jewish polemics as a repetitious and unsavory literary genre, but one whose historical manifestations, nonetheless, provide an important window on Jewish-Christian relations. ${ }^{1}$ For Funkenstein, the twelfth century represents a crucial turning point, when some Christian polemicists promoted a philosophical-rationalist assault on Judaism that identified Jews as irrational and the Talmud as the source of their irrationality. At the vanguard is the Cluniac Abbot Peter the Venerable (d. 1156), who protested in his Adversus Iudeorum inveteratam duritiem (completed ca. 1146-47) that the Talmud is a collection of satanic lies and anti-Christian blasphemies with which rabbinic authorities have long misled Jews and obscured their rational faculty.

Peter the Venerable is the first Latin medieval Christian to identify the Talmud explicitly by name. For his knowledge of the Talmud, however, the Abbot Peter borrowed heavily from the early twelfth-century Dialogus contra Iudaeos by the Jewish convert to Christianity Petrus Alfonsi. Alfonsi's text introduced his Christian readership to numerous Talmudic aggadot-i.e., tales and folklore-in Latin translation in order to condemn the Jews' "foolishness» and irrationality. Alfonsi never named the Talmud as such but instead provided a parallel Latin construction, referring to it as the "teaching» or «sayings of your sages» (doctrina or verba doctorum vestrorum). Despite the absence of the term «Talmud», and even though his Dialogue mentions only tractate Berachot by name, Alfonsi was nevertheless thoroughly acquainted with the Talmud's division into orders (sedarim) and tractates. Alfonsi's Talmudic citations or allusions reveal his familiarity with fifteen tractates from five of the Talmud's six sedarim, from which only seder tohoroth is absent.

Although Peter the Venerable received much of his knowledge of the Talmud from Alfonsi's Dialogus, the abbot learned the name «Talmud» elsewhere. Peter only remarks cryptically that it was Christ himself who revealed to him the Talmud's name and its secrets. He may have learned the name Talmud from Jews living near Cluny, or perhaps he learned it during his visit to Spain in 1142-43, where he had commissioned scholars to prepare Latin translations of Arabic materials (the collectio Toledana or corpus Toledanum) that included the first complete Latin translation of the Qur'an. Just as Peter did not learn the name «Talmud» from Alfonsi's Dialogus, so too he had other sources for Talmudic

${ }^{1}$ Funkenstein, A., Perceptions of Jewish History, Berkeley, L.A., Oxford, University of California Press, 1993, p. 169. 
dicta. This led Yvonne Friedman, the modern editor of Peter the Venerable's Adversus Iudeorum inveteratam duritiem, to speculate that Alfonsi and Peter the Venerable independently accessed an early twelfth-century anthology of Talmudic material. This could explain where Peter the Venerable obtained his knowledge of Talmudic legends absent from Alfonsi's Dialogus as well as why Peter the Venerable, despite his assault on the Talmud, had no clear notion of the Talmud's contents or architecture and organization.

All of this is but a reminder that the Talmud was a source of growing importance for twelfth-century Christian anti-Jewish polemicists. Peter the Venerable claims that the Talmud not only contains blasphemies against Jesus and Mary, but also that Christians are condemned to Hell «[b]ecause they believe in the son of Mary, and they do not observe the law of Moses, and especially because they do not believe in the Talmud.» ${ }^{2}$ Talmud, then, had not only darkened the Jews' reason, but it also poisoned relations between Jews and Christians who «do not believe in the Talmud.»

By the thirteenth-century, awareness of the Talmud will become more widespread among both ecclesiastical and imperial authorities. Despite earlier Christian attacks upon the Talmud, in July 1236 Emperor Frederick II appealed both to the Bible and to the Talmud for positive evidence to refute a blood libel accusation in Fulda directed against Jews of Germany. ${ }^{3}$ Negative views of the Talmud would predominate, however, partly because of the activities of three Jewish converts to Christianity: Nicholas Donin, Pablo Christiani, and Thibaud of Sézanne. Donin was the source of the Thirty-Five Articles against the Talmud presented to Pope Gregory IX in 1238-1239, and was instrumental in the first public disputation that indicted the Talmud in Paris in $1240 .{ }^{4}$ The Jewish convert turned Dominican Pablo Christiani was another prosecution witness against the Talmud, both in the Barcelona disputation of July 1263 and in a second Parisian disputation in 1270.

The Dominicans in particular and the new mendicant orders in general played an important part in the attack upon the Talmud. Nicholas Donin may have had ties to the Dominicans ${ }^{5}$ while Pablo Christiani enjoyed substantial support from the Dominican

\footnotetext{
${ }^{2}$ Adversus Iudeorum inveteratam duritiem, 5, ed. Y. Friedman, CC CM 58, Turnhout, Brepols, 1985, lns. 1371-1375; for English translation, see Peter the Venerable's Against the Inveterate Obduracy of the Jews, trans. I.M. Resnick, Fathers of the Church, Mediaeval Continuation, 14, Washington DC, Catholic University of America Press, 2013, pp. 258-59.

${ }^{3}$ Constitutiones et Acta Publica Imperatorum et Regum, doc. 204, ed. L. Weiland, MGH, LL, sectio 4, vol. 2, Hannover, 1896, pp. 274-276.

${ }^{4}$ See Capelli, P., «Nicholas Donin, the Talmud Trial of 1240, and the Struggles Between Church and State in Medieval Europe» in E. Baumgarten, R. Mazo Karras, and K. Mesler (eds.), Entangled Histories. Knowledge, Authority, and Jewish Culture in the Thirteenth Century, Philadelphia, University of Pennsylvania Press, 2017, pp. 159-180. For a critical edition of the Thirty-Five Articles, see Capelli, P., «De articulis litterarum Papae: A Critical Edition» in A. Fidora and G.K. Hasselhoff (eds.), The Talmud in Dispute during the High Middle Ages, Bellaterra, Universitat Autònoma de Barcelona, Servei de Publicacions, 2019, pp. 29-57.

${ }^{5}$ See Hasselhoff, G.K., Dicit Rabbi Moyses. Studien zum Bild von Moses Maimonides im lateinischen Westen vom 13. bis zum 15. Jahrhundert, Würzburg, Königshausen und Neumann, 2004, $124 \mathrm{f}$.
} 
Order and from Raymund of Peñafort in particular. A third Jewish convert, Thibaud of Sézanne, was subprior of the Dominican priory of Saint James in Paris during the 1240s. In addition, Thomas of Cantimpré reports on efforts of the Dominican Henry of Cologne (i.e., Henry of Marsberg; d. 1254) to confiscate the Talmud in Paris, ${ }^{6}$ in compliance with Pope Gregory IX's order. Henry of Cologne may also have collaborated with Nicholas Donin to produce the Latin Thirty-Five Articles against the Talmud from Donin's medieval French vernacular. ${ }^{7}$ The Thirty-Five Articles were so persuasive an indictment of the Talmud that Pope Gregory IX, in a letter from June 9, 1239, directed the French clergy to confiscate the Talmud, which he ordered burned in 1240.

Although some churchmen sought to defend Jewish communities against efforts to confiscate the Talmud, they were readily demonized. Thomas of Cantimpré records the sudden death of an influential archbishop-likely the Archbishop of Sens Walter of Cornut (d. 1241) - who had allegedly accepted bribes from French Jews to persuade King Louis IX to return confiscated copies of the Talmud. The Jews ordered that the day on which the books were returned be commemorated annually with a solemn observance. Their joy was premature, Thomas remarks, since the following year the archbishop died on that very same day and the king reversed his decision. Thomas claims that he was himself witness to the events which led to the archbishop's untimely and unpleasant death, ostensibly as a divine judgment (Bonum universale de apibus 1.3.6). By 1241-42 King Louis IX had burned twenty wagons loaded with volumes of the Talmud-fourteen on one day and six on another-at the Place de la Grève (Extractiones de Talmud, p. Xxix).

At the time of this concerted assault upon the Talmud dating from the late 1230s, it is clear that its Christian detractors had access to much more of the Talmud than merely those Latin passages employed by Petrus Alfonsi and Peter the Venerable in their twelfth-century polemics. Although Pope Gregory IX's successor Innocent IV was more sympathetic to Jewish protests against the confiscation and burning of the Talmud, Parisian ecclesiastics remained hardened opponents. Soon after his election, French Jews persuaded Pope Innocent IV to order a new investigation of the Talmud. To conduct a review, Innocent IV created a commission of ecclesiastics and university masters which convened under the former university of Paris chancellor Odo of Châteauroux, who had since been named Cardinal Bishop of Tusculum and Apostolic Legate to France. The commission's report, issued in 1248, is signed by numerous high ecclesiastics and university masters. Among them were the Bishop of Paris William of Auvergne, eleven professors of theology (including Albert the Great and university chancellor Walter of Château-Thierry), fourteen professors of decretal law, and twelve other clergy that included the Dominicans Thibaud of Sézanne and Henry of Cologne. Apart from Thibaud of Sézanne, few of the commission members had the

\footnotetext{
${ }^{6}$ Bonum universale de apibus 1.3.6, ed. G. Colvenerius, Douai, Baltazar Bellerus, 1627, pp. 16-17.

${ }^{7}$ See Fidora, A. and Cecini, U., «Nicholas Donin's Thirty-Five Articles Against the Talmud. A Case of Collaborative Translation in Jewish-Christian Polemic», in Ch. Burnett and P. Mantas (eds.), Ex Oriente Lux. Translating Words, Scripts and Styles in Medieval Mediterranean Society, Córdoba, Córdoba University Press, 2016, pp. 187-199.
} 
language skills necessary to read the Talmud in the original. Albert the Great certainly did not. In order to evaluate the Talmud the commission required a Latin translation, then, of the allegedly blasphemous or offensive Talmudic material.

\section{Extractiones de Talmud}

Just such a Latin translation of 1922 passages from the Babylonian Talmud appeared in Paris in 1245 bearing the title Extractiones de Talmud. This text is now available in a first critical edition edited by Ulisse Cecini and Óscar de la Cruz Palma in the Corpus Christianorum series, Continuatio Mediaevalis (CCCM 291). This edition emerged from a wider international team-project, "The Latin Talmud and its Influence on Christian-Jewish Polemic», directed by Alexander Fidora at the Universitat Autònoma de Barcelona and supported by funding from the European Research Council and its Seventh Framework Programme (FP7/2007-2013).

In a lengthy historical introduction, the editors explore the relationship between Nicholas Donin's Thirty-Five Articles against the Talmud and the Extractiones de Talmud, establishing the date for the latter. They also establish that the Extractiones was copied in two different versions: a 'sequential' form that arranged the passages according to their order in the Babylonian Talmud, and a second 'thematic' version that rearranged the excerpts topically according to polemical themes and rubrics. This volume contains the 'sequential' Extractiones; publication of the 'thematic' Extractiones is promised for a forthcoming volume.

The two versions of the Extractiones were accompanied by separate prologues or prefaces, although both prologues are presented in this volume in order better to establish the project's historical context. The prologues establish the project's object, its aim, the translators' methodology, and the individual who commissioned it. The object of the translation is the countless «errors, heresies, blasphemies, and fables» found in the Talmud (p. xlvi); its aim is to lay bare the Jews' perfidy and to remove the veil from their hearts; the translators provide a word for word Latin translation (verbum ex verbo) or a translation according to the meaning or sense of the text (sensum ex sensu); and, Odo of Châteauroux is identified as the individual who commissioned the Extractiones.

The first prologue notes that for the translation, «God provided [to Odo of Châteauroux] two Catholic translators exceedingly skilled in the Hebrew language» (p. 3, lns. 1112; my translation). The two translators worked independently and at different junctures and, although at times their word choices varied on account of the difficulty of the $\mathrm{He}-$ brew text, it insists that they both preserved nonetheless the same sense or meaning throughout. The second prologue, which accompanied the thematic Extractiones, provides a relative chronology for the two translations and makes clear, moreover, that the two «Catholic translators» were, in fact, both converts from Judaism (p. 11).

The editors identify the first of the two translators (interpretes) mentioned in the prologue as Nicholas Donin. The second remains uncertain. The first prologue alludes not only 
to two translators (interpretes), however, but also to «a translator [who] compared the two translations in view of their high degree of similarity» (p. xxiv) and who was responsible for rendering the translation in correct and literary Latin. Even if the two converted Jewish interpretes produced a Latin translation themselves from a vernacular model, «they were nevertheless thinking in Hebrew and French» (p. xlviii) and their style had to be adapted and polished. That was the translator's task. The translator also made decisions over which words would remain in transliterated Hebrew and determined when a gloss was necessary. Transliterated Hebrew words and Gallic terms in the Extractiones are listed at the end of the volume in an Index verborum Hebraicorum and an Index verborum Gallicorum, both compiled by Eulàlia Vernet i Pons. The translator also decided which translated passages should appear in the final version of the Extractiones. Although the editors have identified Donin as one of the interpretes, the identity of the other and of the translator remains uncertain.

Although Gilbert Dahan had previously argued that on the basis of similarities with Thibaud of Sézanne's Errores iudaeorum Thibaud must have been one of the interpretes of the Extractiones, the editors endorse Alexander Fidora's argument that Thibaud's text displays similarities only to the second, 'thematic' version of the Extractiones; therefore, it is unlikely that Thibaud was one of the translators of the 'sequential' Extractiones. Gilbert Dahan had also suggested that Henry of Cologne served as translator. While the editors view Henry as possibly the translator, they conclude that «definitive evidence in this respect remains a desideratum» (p. xxv).

The Extractiones were produced in Paris during a period from 1236 until 1248 when the Talmud had become a special object of Christian polemics. As such, the Extractiones was conveyed with numerous related documents to form a Talmud controversy «dossier» transmitted in seven manuscripts. The dossier is divided into two parts with each having its own prologue. The first part of the dossier contains the 'sequential' Extractiones along with a Latin translation of liturgical hymns said to contain anti-Christian material, the Liber Krubot (Sefer Qerubot). ${ }^{8}$ Following a prologue to the second part, the second part of the dossier includes Donin's Thirty-Five Articles against the Talmud; papal letters to ecclesiastics and secular rulers, and their replies; and, an anthology of 76 Latin Talmud passages that may have been prepared at the same time as Donin's Thirty-Five Articles but which were omitted from that work. ${ }^{9}$ The second part also contains selections from Rashi's glosses to the Old Testament which, its prologue alleges, so perverted and corrupted the meaning of the biblical text as to overthrow all spiritual understanding, while the Jews endow his words with an authority as if they were spoken from God's own mouth (p. 16, lns.179-185). In addition, the second part includes the statements of the two rabbis

\footnotetext{
${ }^{8}$ Görge K. Hasselhoff has published an edition of the Latin De libro Krubot as an appendix to Wout van Bekkum's «The Latin Talmud and Liber Krúbot», in The Talmud in Dispute during the High Middle Ages, op. cit., pp. 203-215.

${ }^{9}$ For a critical edition of this anthology of texts, see Cecini, U. and de la Cruz Palma, Ó., «Beyond the Thirty-Five Articles: Nicholas Donin's Latin Anthology of the Talmud (With a Critical Edition)», in The Talmud in Dispute during the High Middle Ages, op. cit., pp. 59-99.
} 
questioned during the inquiry in Paris in 1240, namely R. Yehiel of Paris and R. Iudas (Judah of Melun); a short list of individual rabbis' names (found in the Index magistrorum compiled by Eulàlia Vernet i Pons); and, the final sentence of condemnation issued in 1248 and signed by the members of the Parisian commission. It concludes with a short explicit.

As an aide to medieval Christian readers, the author of the first prologue provided not only an introduction to the orders and tractates of the Talmud and its role in Jewish thought and practice, but also an explanation of the meaning of certain Hebrew words in contemporary use (p. 1). Paragraphs 39-42 of the prologue provide a transcription of Hebrew phonetics into Latin and explain some Hebrew vocalic sounds with reference to medieval French, providing insight into Hebrew pronunciation in thirteenth-century Paris (p. lii). In a fascinating digression, the prologue's author explains that he has provided information on Hebrew pronunciation because a Christian will not be taken seriously in a disputation with Jews if he cannot pronounce the Hebrew properly (p. lii).

The 'thematic' Extractiones was later compiled using the materials found in the dossier. A second and slightly different prologue was attached to the 'thematic' Extractiones, which is bound at the beginning of the most complete manuscript witness to the dossiers, viz., Paris, Bibliothèque nationale de France, lat. 16558, which dates from the thirteenth century. Because the 'thematic' Extractiones has its own manuscript tradition, however, the editors plan for it to appear in a separate volume. Despite the absence of the 'thematic' version in the present volume, almost all of the translated Talmud passages in the 'sequential' Extractiones were classified in the manuscript margins according to topical rubrics used later in the 'thematic' Extractiones. The editors have included at the end of this volume an Index categoriarum locorum de Talmud which records these classifications and the Talmud passages that correspond to them, making it possible to anticipate the rearrangement of the thematic version. Included among these rubrics are: blasphemies against Christ and the Blessed Virgin; blasphemies against God; against Christians; on the World to Come; and, on the Messiah.

The Extractiones translates an exemplar of Talmud that first presents an entire chapter of Mishnah followed by its Gemara; the latter consistently quotes the beginning of the Mishnah subsection to which it refers. Mishna quotations are arranged in an Index locorum de Misna at the end of this volume. Throughout this edition, Talmud passages are identified according to the conventions used in the Vilna Talmud. Some differences in pagination arise, which the editors attribute to scribal error: viz., the scribe sometimes read the Latin Talmud passages presented in the manuscript margins from left to right rather than right to left, so that the passages appear in reverse order. This too is remedied by an Index locorum ex Talmud that enables the reader to find each passage according to its pagination in the Vilna Talmud.

The Rashi glosses in the Extractiones are exceedingly numerous and the translator interpolates them into the Talmud text itself in order to make it more comprehensible. Other rabbinical commentaries are used sporadically. The translator often adds his own explanations to clarify words or arguments for the Christian reader. For this edition, the 
editors identify all such exegetical interventions with a reduced font inserted between dashes. Federico Dal Bo has produced at the end of this volume a preliminary Appendix glossarum containing the glosses found in the Extractiones.

The translator identified biblical quotations (with the exception of the Psalms) found in the Talmud in the body of the Extractiones by book and chapter number; sometimes biblical passages are further identified with a letter indicating a chapter subsection. The translator typically cites the Latin biblical passage according to the Vulgate (Paris recension). The modern editors expand the biblical citations to include book, chapter, and verse within parentheses in the text. After providing the biblical passage based on the Latin Vulgate, the translator also added a literal translation of the Hebrew passage, especially when the Talmudic explanation is based on a word not found in the Vulgate. This juxtaposition of the Hebrew and Vulgate passages also reveals their differences and likely contributed to later medieval efforts to correct the Vulgate text.

On pp. lxiii-lxxix the editors provide a codicological description of the manuscripts that preserve the Extractiones. A study of the stemma codicum (pp. lxxix-lxxxiv), moreover, leads them to propose that the Extractiones underwent four stages of development:

1. A first stage likely relies upon a Latin translation of Talmud passages annotated in the margins of a Hebrew/Aramaic manuscript preserved uniquely in Florence, Bibliotheca Nazionale Centrale, coll. Antonio Magliabechi, II-I-7, 8 and 9, whose oldest portion dates to 1177. The Florence manuscript, as Ulisse Cecini has shown elsewhere ${ }^{10}$ displays in the margins around its main text many of the Latin Talmud passages later found in the Extractiones. The editors suggest, then, that the Latin Talmud passages would initially have been included in a bilingual manuscript (like the Florence manuscript) and that subsequently the Latin text was copied separately.

2. In a second stage, the Latin text was detached from a bilingual exemplar. This is visible in Berlin, Staatsbibliothek Preussischer Kulturbesitz, Ms. theol. lat. fol. 306, which is closely linked to the Florence manuscript.

3. In a third stage, the detached Latin text underwent stylistic emendations and a further selection of passages. The Girona codex, Arxiu Capitular, ms. 19b, and Carpentras, Bibliothèque Inguimbertine, lat. 153, are variants of this stage.

4. In a fourth stage, the Extractiones is included in its most well-known witness, Bibliothèque nationale de France, lat. 16558. Although this can be considered the codex antiquissimus et optimus, it is the product of a process of emendation outlined in the three earlier stages.

${ }^{10}$ Cecini, U., «The Extractiones de Talmud and their Relationship to the Hebrew Talmud Manuscripts of the Biblioteca Nazionale Centrale of Florence (MS Magl. Coll. II.I.7, 8 and 9)», Sefarad, 77/1 (2017), pp. 91-115. 
At the bottom of each page of text the editors provide critical apparatuses. There are four additional apparatuses in the text: a biblical apparatus; an apparatus fontium; a traditio textus; and the apparatus marginalium. The first records observations concerning biblical citations; the second includes internal references to other parts of Talmud; the third indicates which manuscript transmits a given passage; the last contains marginal classifications of passages as well as other marginal annotations.

The Extractiones is a complex text, and the editors helpfully provide a fully annotated sample page from the edition (pp. xcvi-xcviii), followed by a bibliography (pp. xcix-cvi); a list of abbreviations (pp.cvi-cix); and editorial signa and sigla used for codices and editions (pp. cix-cx). Following these is the text of the 'sequential' Extractiones (pp. 3-514), and the various indices: Index locorum ex Talmud translatorum; Index locorum de Misna; Index locorum S. Scripturae; Index categoriarum locorum de Talmud; Index magistrorum (by Eulàlia Vernet i Pons); Index verborum Hebraicorum (by Eulàlia Vernet i Pons); Index verborum Gallicorum (by Eulàlia Vernet i Pons); and an Appendix glossarum (by Federico Dal Bo).

It is difficult to overstate the significance of this edition. The Extractiones presents medievalists with the Latin Talmud which is at the center of thirteenth-century Christian-Jewish disputations and polemics and which also influenced later anti-Jewish sermons. ${ }^{11}$ Furthermore, the edition provides a useful resource for an examination of the historical development of the text of the Talmud itself. Because of Christian censorship many printed editions of the Babylonian Talmud, including the Vilna edition, are lacking certain 'offensive' passages, or these were preserved only in a more «polished» language. For example, according to the translator's prologue to the Extractiones, the word goy had come to designate Christians in particular. In the Vilna Talmud goy is often replaced with 'obed kokabîm or "worshipper of the stars», to indicate a pagan rather than a Christian. The editors note that «Some of these missing passages or original terms have, in fact, been translated into Latin and survive in the Extractiones» (p. xvii). Finally, as already indicated, the prologue to the Extractiones provides information on medieval Hebrew terms and pronunciation, making its own contribution to Hebrew and Romance philology. The Extractiones will undoubtedly prove useful to a wide scholarly audience.

${ }^{11}$ Fidora, A., «The Influence of the Extractiones de Talmud on Anti-Jewish Sermons from the Thirteenth and Early Fourteenth Centuries», inThe Talmud in Dispute during the High Middle Ages, op. cit., pp. 235-47. 